\title{
Analisis Permasalahan Konselor Sekolah Dalam Penyelenggaraan Layanan Bimbingan Dan Konseling
}

\author{
Faijin, Nurhayati, Amiruddin \\ Prodi Bimbingan dan Konseling, STKIP Bima \\ wongfaijin@gmail.com
}

\begin{abstract}
Abstrak
Memiliki pemahaman konsep dasar konselor dengan baik berimplikasi pada kemampuan konselor sekolah dalam mengaplikasikan layanan bimbingan dan konseling secara ideal. Kenyataannya yang terjadi dilapangan masih terdapat banyak kekurangan, hal ini pula yang mendesak semua komponen pendidikan khususnya konselor untuk melakukan usaha perbaikan. Oleh sebab itu peningkatan kompetensi konselor sekolah baik kompetensi keilmuan, kompetensi keahlian, maupun kompetensi perilaku akan mewujudkan pelaksanaan program bimbingan dan konseling secara jelas, terarah dan sistematis. Tujuan peneliitian ini adalah untuk mendapatkan gambaran tentang hambatan yang dihadapi konselor sekolah dalam penyelenggaraan layanan bimbingan dan konseling disekolah. Sedangkan manfaat penelitian adalah untuk memberikan kontribusi bagi perguruan tinggi khususnya program bimbingan dan konseling dalam menyeleksi calon mahasiswa dan dinas terkait didalam menyeleksi calon konselor sekolah.Penelitian inidilakukan di sekolah SMA NEGERI 1 LANGGUDU, bersifat non-eksperimen dan jenisnya adalah bersifat deskriptif dengan menggunakan paradigma kualitatif. Subyek penelitian adalah personel sekolah sebanyak 3 orang, adapun instrument yang digunakan dalam penelitian ini adalah pedoman wawancara,observasi dan didukung oleh data dokumentasi. Proses pengumpulan data dilakukan dengan menentukan jenis data, pengumpulan data, dan pengecekan keabsahan data. Tehnik analisa data yang digunakan adalah tehnik analisa data kualitatif yang terdiri dari reduksi data, penyajian data dan penarikan kesimpulan.
\end{abstract}

KataKunci: Konselor sekolah, Layanan bimbingan dan konseling dan pemecahanya.

\section{PENDAHULUAN}

Dengan berlakunya Undang-Undang No. 20 Tahun 2003 Tentang Sistem Pendidikan Nasional yang bertujuan mengembangkan kemampuan dan membentuk watak serta peradabban bangsa yang bermartabat, dalam rangka mencerdaskan kehidupan bangsa,mengembangkan potensi peserta didik agar menjadi manisia yang beriman dan bertaqwa kepada Tuhan Yang Maha Esa, berakhlak mulia, sehat, berilmu, cakap,kreatif, mandiri, dan menjadi warga Negara yang demokratis serta bertanggung jawab dan Peraturan Pemerintah RI No 19 Tahun 2005 Tentang Badan Standar Nasional Pendidikan (BSNP), serta Peraturan Menteri Pendidikan Nasional No. 22, 23, 24 Tahun 2006 Tentang Standar Kompetensi, Standar Isi, dan Standar kelulusan bahwa satuan pendidikan dasar dan menengah dituntut untuk mengembangkan serta melaksanakan Kurikulum Pendidikan sesuai dengan kebijakan yang ada dan mengacu kepada ketentuan-ketentuan yang berlaku 
(PERMEN,2006). Pelayanan bimbingan dankonseling di sekolah dari tingkat Sekolah Dasar hingga Perguruan Tinggi dewasa ini semakin dibutuhkan. Optimalisasi pelayanan bimbingan dan konseling di sekolah perlu dilakukan sehingga pelayanan bimbingan dan konseling di sekolah benar-benar memberikan kontribusi dan pencapaian Visi, Misi dan tujuan sekolah yang bersangkutan (Prayitno, 2005). Untuk itu upaya peningkatan mutu pendidikan harus dilakukan secara menyeluruh yang mencakup pengembangan dimensi manusia seutuhnya yakni aspek kognitif, afektif, dan psikomotor. Pengembangan aspek-aspek tersebut bermuara pada peningkatan dan pengembanga kecakapan dan gaya hidup (life skill) yang terwujud melalui pencapaian kompetensi peserta didik untuk bertahan hidup, menyesuaikan diri, dan berhasil di masa datang. Dengan demikian peserta didik memiliki kemandirian dan jatidiri yang dikembangkan melalui pembelajaran dan pelatihan.

Upaya peningkatan mutu pendidikan adalah melakukan perubahan untuk menuju sebuah perbaikan yang selalu disertai dengan konsekwensi-konsekwensi yang sudah selayaknya dipertimbangkan agar tumbuh kebijaksanaan melalui olah hati, olah piker, olah rasa dan olah raga agar memiliki daya saing dalam menghadapi tantangan global.

Pelaksanaan bimbingan dan konseling selama ini masih dalam tahap yang kurang memuaskan, walaupun pada sekolah-sekolah negeri maupun swasta telah

ditempatkan tenaga-tenaga profersional, hal ini sebagai konsekwensi akibat penyelenggaraan kurikulum yang selalu berubah-ubah sehingga berdampak pula pada penerapan layanan bimbingan dan konseling. Untuk itu peneliti berusaha mengkaji dan memahami keadaan tersebut dan kemudian berupaya untuk menemukan upaya pemecahanya jika ada permasalahan yang dihadapi melalui penelitian yang berjudul "Analisis Permasalahan Konselor Sekolah dalam Penyelenggaraan Layanan Bimbingan dan Konseling dan Upaya Pemecahanya pada Sekolah Menengan Atas(SMA) Negeri 1 Langgudu Bima.

\section{METODE}

Sesuai pendekatan yang digunakan daalam penelitian ini yaitu pendekatan kualitatif, maka kehadiran peneliti dilapangan merupakan hal yang sangat penting karena peneliti bertindak sebagai instrument utama dan sekaligus sebagai pengumpul data penelitian yang diperlukan. Menurut Bogdan dan Biklen (dalam Moleong, 2001) menyatakan bahwa sebagai instrument kunci, peneliti harus dapat menangkap makna dan berinteraksi terhadap nilai-nilai lokal. Penelitian ini dilaksanakan di SMA Negeri 1 Langgudu. Dalam rangka pengumpulan data sesuai denga keperluan secara menyeluruh dan mendalam sesuai dengan data yang diperoleh dalam penelitian ini, berkaitan dengan perilaku subyek dalam penyelenggaraan layanan bimbingan dan konseling, maka dalam pengumpulan data menggunakan tiga tehnik yaitu: 1). Tehnik Observasi, 2). Tehnik wawancara mendalam, da, 3). Tehnik studi Dokumentasi.

Dalam menganalisa data dilakukan prosedur sebagai berikut:

\section{1). Reduksi Data}

Data yang telah dikumpulkan kemudian dicermati, diedit, diberi kode dan dipilah antara data yang diperlukan. Data yang terkait dengan penelitian kemudian diklarifikasi dan diberi pengkodean sesuai dengan tujuan penelitian. Mengenai data yang tidak memiliki hubungan dengan penelitian ini untuk sementara diabaikan.

2). Penyajian Data 
Data yang sudah diedit, diklarifikasi, diberi kode,kemudian diorganisir secara keselirihan. Data yang sifatnya kuantitatif yang diperlukan dalan pengumpulan data ini disajikan dalam bentuk table. Sedangkan data yang sifatnya deskriptif seperti: makna, perilaku, konsep, alas an dan pertanyaan disajikan

dalam bentuk naratif deskriptif.

3). Penarikan Kesimpulan

Kegiatan ini adalah merupakan langkah terakhir yang akan dilakukan dalam kegiatan analisa data. Data yang telah direduksi dan diorganisir dalam bentuk penyajian data kemudian disimpulkan sesuai dengan arah penelitian. Dalam penelitian ini mengguanakan tiga criteria pengecekan keabsahan data yaitu: 1). Kredibilitas untuk aspek kebenaran data, 2).dependabilitas untuk aspek konsistensinya, dan 3).konfirmabilitas untuk aspek netralisasinya.

\section{HASIL DAN PEMBAHASAN}

Keberadaan konselor sekolah dalam system pendidikan nasional dinyatakan sebagai salah satu kualifikasi pendidik, sejajar dengan kualifikasi guru, dosen, pamong belajar, tutor, widiyaswara, fasilitator dan instruktur (UU No.20 Tahun 2003 Pasal 1 Ayat 6). Kesejajaran posisi ini tidaklah berarti bahwa semua tenaga pendidik itu tanpa keunikan konteks tugas dan ekspektasi kinerja.

Berdasarkan hasil analisa data diatas, memberikan gambaran betapa pentingnya keberadaan konselor sekolah pada setiap jenjang pendidikan formal

untuk memberikan pelayanan khusus bimbingan dan konseling dalam membantu arah pengembangan diri siswa. Dalam usaha penyelenggaraan layanan bimbingan

dan konseling khususnya di SMA Negeri 1 Langgudu belum optimal, hal ini didasarkan pada keterangan yang peneliti kaji dari berbagai sumber data seperti

Kepala Sekolah, wali kelas, guru mata pelajaran, siswa, orang tua siswa dan konselor sekolah. Persoalan yang muncul dalam pelayanan bimbingan dan konseling, selain disebabkan oleh kurangnya dukungan sarana dan prasarana pendukung layanan, juga disebabkan oleh kurangnya kompetensi konselor sendiri sebagai pribadi yang paling bertanggungjawab dalam pelayanan bimbingan dan konseling. Persoalan profesionalitas layanan, akan ditentukan oleh kemampuan konselor yang mumpuni, memiliki kompetensi pedagogik, kompetensi kepribadian, kompetensi sosial dan kompetensi profesional. Kompetensi professional konselor adalah kiat dalam penyelenggaraan layanan bimbingan dan konseling yang memandirikan, yang ditumbuhkan serta diasah melalui latihan dalam konteks otentik di lapangan yang dikemas sebagai Pendidikan Profesi Konselor (PPK). Keberhasilan menempuh dengan baik program PPK ini bermuara pada penganugerahan sertifikat profesi bimbingan dan konseling yang dinamakan Sertifikat Konselor,dan gelar profesi Konselor di singkat Kons.

\section{PENUTUP}

Berdasarkan hasil wawancara terhadap berbagai sumber data bahwa penyelenggaraan layanan bimbingan dan konseling sudah diupayakan dengan maksimal tetapi masih ditemukan berbagai hambatan akibat tidak tersedianya fasilitas pendukung seperti ruang bimbingan dan konseling yang ideal sehingga sebagian dari program layanan yang memerlukan tempat dan ruangan khusus seperti layanan bimbingan kelompok, konseling kelompok, dan konseling individual tidak bisa dioptimalkan. 
Solusi dari kesimpulan diatas adalah diharapkan kepada Kepala Sekolah sebagai penanggungjawab utama kegiatan bimbingan dan konseling memberikan perhatian khusus dengan mempersiapkan ruangan khusus bimbingan dan konseling yang ideal sesuai dengan standar nasional. Tingkat kerjasama yang dilakukan konselor sekolah dengan personil bimbingan dan konseling yang lain sudah dianggap maksimal, hal ini bisa dilihat dari proses penanganan kasus dengan selalu melibatkan personil lain seperti guru bidang studi, wali kelas, orang tua siswa, dan pihak-pihak terkait dengan melakukan tukar informasi kaitanya dengan kondisi dan keadaan siswa baik yang terjadi pada saat siswa ada di sekolah, dalam ruangan belajar, maupun diluar sekolah seperti lingkungan social dan lingkungan keluarga (rumah). Dukungan Kepala Sekolah dan personil lain dalam memasyarakatkan layanan bimbingan dan konseling sangat baik, hal ini terlihat dengan selalu memberikan kesempatan kepada konseloe sekolah untuk berbicara dan mensosialisasikan program yang dibuat pada rapat dan musyawarah yang dilakukan pada setiap hari senin. Kemampuan dan pemahaman konselor sekolah tentang layanan bimbingan dan konseling terutama dalam aplikasi instrumentasi seperti tes dan instrument non tes masih dianggap kurang, semestinya konselor sekolah harus mampu mengasai dan memahami serta mengaplikasikan instrument tersebut sebagai pendukung kegiatan bimbingan dan konseling terutama dalam memahami potensi yang ada dalam diri individu. Untuk itu konselor sekolah harus mampu meningkatkan profesionalitas dengan sering mengikuti latihan-latihan, seminar, diklat, maupun pendidikan profesi konselor serta kegiatan serupa yang lain dalam meningkatkan kompetensi individual maupun kompetensi paedagogik terutama yang berkaitan dengan layanan bimbingan dan konseling.

\section{Saran-Saran}

1. Konselor Sekolah

Diharapkan kepada para konselor sekolah untuk selalu berusaha dalam meningkatkan kompetensi individual maupun kompetensi paedagogik serta pengembangan profesionalitas melalui latihan-latihan, diklat, seminar, workshop bahkan menempuh studi lanjutan khusus atau pendidikan profesi konselor agar memiliki kompetensi dalam aspek kognitif, afektif, dan psikomotor guna mewujudkan pribadi konselor yang memiliki kemampuan sebagai seorang yang professional.

2. Kepala Sekolah

Sebagai penanggungjawab kegiatan bimbingan dan konseling, Kepala sekolah harus bisa membaca kebutuhan para personil bimbingan dan konseling yang ideal agar dipersiapkan secepatnya guna mendukung terselenggaranya kegiatan bimbingan dan konseling yang optimal.

3. Lembaga Pendidikan

Dalam mewujudkan sarjana (S1) bimbingan dan konseling yang memiliki wawasan baik dalan aspek afektif, kognitif, maupun psikomotor serta memenuhi tuntutan perkembangan menurut kaidah keilmuan dan kode etik bimbingan dan konseling.

4. Dikpora

Sebagai optimalisasi kegiatan layanan bimbingan dan konseling diharapkan kepada seluruh dinas terkait agar memberikan peluang dan meningkatkan jumlah konselor sekolah pada setiap jenjang pendidikan sesuai dengan rasio penanganan siswa yaitu satu orang konselor sekolah untuk 150 orang siswa.

\section{DAFTAR PUSTAKA}

[1] Abu Ahmadi, 1997. Bimbingan dan Penyuluhan di Sekolah, CV Toha Putra Semarang. 
[2] Depdiknas, 2003. Undang-Undang Republik Indonesia Nomor 20 Tahun 2003 tentang Sistem Pendidikan Nasional. Depdiknas, Jakarta.

[3] Enre Abdullah, 1995. Identifikasi Kebutuhan Masalah dan Tantangan BK dan Implikasinya bagi Pengembangan Profil Konselor Abad XXI. Konvensi Nasional X dalam Kongres Nasional. Surabaya.

[4] Mapiare Andi, 1984. Pengantar Bimbingan dan Konseling di Sekolah, Usaha Nasional Surabaya.

[5] Milles, Mattew B dan Hubberman, A Michael, 1992. Analisa Data Kualitatif. Penerjemah Tjejep Rohendi Rosidi, Pustaka Nasional UI-Press Jakarta.

[6] Moleong Lexy, 1991. Metodologi Penelitian Kualitatif, PT. Remaja Rosada Karya Bandung.

[7] Mulyadin, Agus, dan Ahmad, 2003. Pengelolaan Bimbingan dan Konseling di Sekolah. Depdiknas, Jakarta.

[8] Peraturan menteri Pendidikan Nasional No. 27. 2008. Standar Kompetensi Konselor, Jakarta.

[9] Sudjana Nana, 1987. Tuntunan Penyusunan Karya Ilmiah. Penerbit Sinar Baru. Bandung.

[10] Sukardi Ketut, 1983. Dasar-Dasar Bimbingan dan Penyuluhan di Sekolah, Penerbit Usaha Nasional.Surabaya.

[11] Penataan Pendidikan Profesional Konselor dan Layanan Bimbingan dan Konseling Dalam Jalur Pendidikan Formal, 2007. Standar Kompetensi Konselor. Dirjen Dikti Depdiknas. 